Pegem Journal of Education \& Instruction, 3(4), 2013, 57-68

Pegem Eğitim ve Öğretim Dergisi, 3(4), 2013, 57-68

www.pegegog.net

KOLAYLAŞTIRICI OKUL YAPISI ÖLÇEĞININ TÜRKÇE FORMUNUN PSIKOMETRIK ÖZELLIKLERINNIN YENIDEN DEĞERLENDIRILMESi

\title{
REASSESING THE PSYCHOMETRIC PROPERTIES OF THE TURKISH VERSION OF ENABLING SCHOOL STRUCTURE SCALE
}

\author{
Niyazi ÖZER ${ }^{* *}$, Burhanettin DÖNMEZ \\ İnönü Üniversitesi, Eğitim Fakültesi, Malatya/Türkiye
}

\section{Öz}

Bu araştırma ile okullardaki bürokratik yapının kolaylaştırıcı mı engelleyici mi olduğunu belirlemek üzere geliştirilen "Kolaylaştırıcı Okul Yapısı Ölçeği”nin psikometrik özelliklerinin incelenmesi, geçerlik ve güvenirlik çalışmalarının yapııması amaçlanmıştır. Araştırmanın katılımcıları, 2009-2010 eğitim-öğretim yılında, Malatya ili merkez ilçe belediye sınırları içerisinde yer alan 75 farklı ilköğretim okulunda görev yapan toplam 1018 öğretmenden oluşmaktadır. Araştırmada geçerlik çalışmaları kapsamında açımlayıcı ve doğrulayıcı faktör analizi ve düzeltilmiş madde-toplam korelasyon katsayıları hesaplanmış, güvenirlik çalışmaları kapsamında iç tutarlık katsayıları hesaplanmıştır. Geçerlik ve güvenirlik çalışmalarından elde edilen bulgular sonucunda, tek faktörlü bir yapıya sahip olan orijinal ölçek formunun aksine, Türkçe formunun kolaylaştırıcı bürokrasi ve engelleyici bürokrasi olmak üzere iki faktörden oluştuğu belirlenmiştir. Engelleyici bürokrasi boyutunda yer alan maddelerin faktör yükleri ".557" ile ".832" arasında değişirken, kolaylaştırıcı bürokrasi boyutunda yer alan maddelerin faktör yüklerinin ".485" ile “.785” arasında değişmektedir. Oniki maddeden oluşan ölçekte yer alan maddeler toplam varyansın yaklaşık olarak \% 51'ini açıklamaktadır. Ölçeğin Cronbach Alpha iç tutarlıık katsayıları kolaylaştırıcı bürokrasi boyutu için ".806", engelleyici bürokrasi için ise ".774" olarak hesaplanmıştır. Analizler sonucunda elde edilen bu değerlerden hareketle ölçeğin Türkçe formunun, tek faktörlü değil iki faktörlü olarak kullanılmasının daha uygun olduğu söylenebilir.

Anahtar kelimeler: Bürokrasi, bürokratik yapı, ilköğretim okulları, ölçek uyarlama.

\begin{abstract}
The purpose of this research is to investigate the psychometric properties of the Enabling School Structure Scale (ESS) that aims to measure the degree to which school structure is enabling or coercive, and also to conduct reliability and validity studies of the scale. Participants of the study consisted of 1018 teachers working in 75 different primary schools located in Malatya province during 2009-2010 semester. For validity studies, exploratory and confirmatory factor analyses were carried out, and also corrected item-total correlations were estimated. For reliability studies, Cronbach Alpha and test-retest correlation coefficients were estimated. Results obtained from the reliability and validity studies showed that on the contrary to original form of ESS, Turkish form consisted of two distinct factors, enabling bureaucracy and coercive bureaucracy respectively. While factor loading of the items in enabling
\end{abstract}

* Bu çalışma, Prof. Dr. Burhanettin DÖNMEZ danışmanlığında yürütülen “ilköğretim Okullarının Örgütsel Diriklik, Bürokratiklik ve Örgüt Normları Açısından Analizi" başlıklı doktora tezinden üretilmiştir.

** Yazar: niyazi.ozer@inonu.edu.tr 
bureaucracy range between ".557" and ".832", factor loadings of items in coercive bureaucracy range between ".485" and ".785". It was also found that this 12 itemed two-factor solution explained approximately a total of $51 \%$ of the total variance. Estimated Cronbach alpha coefficients were ".806" for enabling bureaucracy sub-scale and ".774" for coercive bureaucracy sub-scale. Consequently it can be asserted that Turkish form of the ESS scale should be used with two factor structure not one single structure.

Keywords: Bureaucracy, bureaucratic structure, primary schools, scale adaptation.

\section{Giriş}

Yönetim alan yazınında, tarihi gelişimleri açısından klasik, neo-klasik ve modern olmak üzere üç farklı yönetim kuramından söz edilmektedir (Aydın, 2007; Balcı, 1991). Farklı dönemlerde yaşanan toplumsal olayların bir sonucu olarak ortaya çıkan bu kuramlardan, klasik yönetim akımının gelişiminde; bürokrasi, yönetim kuramı ve bilimsel yönetim düşünce akımları rol oynamaktadır (Aydın, 2007). Özde aynı varsayımlara dayanmasına rağmen, birbirinden ayrı çalışan yönetim ve toplum bilimciler tarafından geliştirilen bu düşünce akımlarına göre örgütler, büyük ölçüde mekanik ve rasyonel sistemler olarak algılanmış (Aydın, 2007), yönetim ekonomik etkinlik ölçütüne göre değerlendirilmiştir (Balcı, 1991).

Bir örgüt ve yönetim biçimi olarak, klasik yönetim kuramı kapsamında incelenen bürokrasinin, terim olarak, ilk defa 1745 'de Fransa'da devrin ticaret bakanı, fizyokrat Vincent de Gournay tarafından kullanıldığı ifade edilmektedir (Yayla, 2001). Bürokrasi olarak adlandırılmış olmasa da, klasik kuramın ve bürokrasinin bazı öğelerine sahip örgütlerin varlığı binlerce yıl öncesine dayanmaktadır (Aydın, 2007). Örneğin yeni imparatorluk döneminde Mısır'da, Roma Katolik Kilisesinde, Bizans İmparatorluğu'nda ve Çin'de, tarihsel olarak önemli ölçüde gelişmiş geniş bürokratik örgütlerin var olduğu belirtilmektedir (Aydın, 2007; Öztürk, 2001; Weber, 1996).

Yönetim alan yazınında, daha çok Alman düşünür ve sosyolog Max Weber ile birlikte anılan bürokrasi teriminin etimolojik olarak, devlet işlemlerinin yapıldığı daireler anlamına gelen "burea" kavramı ile eski Yunanca'da "iktidar" ya da "hakimiyet" anlamına gelen "cratie" sözcüklerinden türediği ifade edilmektedir (Öztürk, 2001). Her iki sözcüğün birleşmesiyle oluşan kavram, devlet dairelerinin egemen olduğu sistem anlamına gelmektedir. Ancak günümüzde bürokrasi terimi birbirinden farklı ve zıt anlamlarda kullanılmaktadır. Örneğin bürokrasi kavramı, "tüm devlet örgüt ve personelini tanımlamak", "belli bir örgütlenme ve yönetim biçimini belirtmek" ve "örgüt içinde yaşanan kâğıt hamallığını ya da kırtasiyeciliği açıklamak” (Tortop, İşbir ve Aykaç,1993) için kullanılmaktadır.

Max Weber, modern bir örgüt yapısının etkili ve verimli olabilmesi için bürokratik özelliklere sahip olması gerektiğini belirtmektedir (Etzioni, 1964). Çünkü bürokrasinin oluşturulmasının temelinde; düzensizlik, karışıklık ve kararsızlıktan kurtulmak, örgütleri belli bir yapıya, düzene ve kararlılığa kavuşma isteği yatmaktadır (Aydın, 2007). Bürokrasi kuramı, bir örgütte bireyler arasındaki ilişkileri etkilemek ya da belirlemek üzere, bir örgüt yapısının oluşturulması noktasından hareket etmektedir (Hall, 1963).

Weberin ideal tip olarak adlandırdığı yapıda, örgüt içerisindeki görevler, hiyerarşik bir yapı içerisindeki farklı konumlar arasında dağıtıımıştır (Aydın, 2007; Bursalıoğlu, 2003; Hoy ve Miskel, 2010). Örgütteki konumlar arasında açık ve net bir iş bölümünün olması, ileri ölçüde bir uzmanlaşmayı sağlamaktadır (Aydın, 2007). Örgüt içindeki konumlar ya da birimler, genellikle piramit biçimindeki hiyerarşik bir yapı içinde örgütlenmektedir. Bu yapı içinde her konumda bulunan görevli, kendi karar ve eylemlerinden dolayı bir üst amirine karşı sorumlu olduğu gibi, kendine bağlı astların karar ve eylemlerinden de sorumludur (Aydın, 2007). Hiyerarşik yapı ile örgüt içerisindeki hiçbir birim kontrolsüz bırakılmadığı gibi, itaat sistematik bir şekilde kontrol edilir (Etzioni, 1964). Örgütteki resmi karar ve eylemler, oluşturulan resmi ya da teknik kurallar, düzenlemeler ve normlar tarafından belirlenmektedir (Aydın, 2007; Etzioni, 1964). Görevlilerin, müşteriler ve örgüt içerisindeki diğer görevlilerle olan ilişki ve iletişimlerinde nesnel bir eğilim sergilemesi gerekmektedir (Hoy ve Miskel, 2010; Yücel, 1999). Örgütte 
görev alma, bireyler için sürekli bir iş garantisi sağlar. İşe personel almada temel ölçüt, teknik yeterliktir (Aydın, 2007). Deneyim ve başarıya dayanan bir terfi sistemi vardır, terfiler üstlerin değerlendirmesine göre yapılır (Öztürk, 2001). Çalışanların ve yöneticilerin, kendilerine verilen görevleri yürütmek için gerekli olan kaynaklar üzerinde mülkiyet hakları yoktur. Kaynaklar, örgütün ihtiyaçlarına göre dağıtılır ve kullanılır (Etzioni, 1964; Zeytin, 2009).

İlgili alan yazında, bir örgütün bürokratik bir yapıya sahip olup olmadığı ya da ne düzeyde bürokratik olduğunu belirleme noktasında bütünsel ya da boyutlu olmak üzere iki farklı yaklaşım bulunmaktadır (Hall, 1963; Yücel, 1999; Udy, 1958; 1959). Bütünsel yaklaşıma göre, bir örgüt ya bürokratiktir ya da değildir. Bu yaklaşımı benimseyen araştırmacılar, bir örgütün bürokratik olarak nitelendirilebilmesi için, o örgütte bütün bürokratik özelliklerin üst düzeyde gözlenmesi gerektiğini belirtmektedir (Yücel, 1999). Boyutlu yaklaşıma göre ise, bir örgüt bir boyutu ile oldukça bürokratik bir özellik gösterebilirken, diğer boyutu ile göstermeyebilir (Hall, 1963; Yücel, 1999). Bir diğer ifadeyle, örgütler sahip oldukları bürokratik özellikler açısından az bürokratik ya da çok bürokratik arasındaki bir çizgi üzerinde yer almaktadır (Hall, 1963). Weber ideal tip bürokrasi olarak nitelendirdiği örgüt modelinde, bürokratik örgütü boyutlu bir bakış açısıyla incelemiştir. Ancak gerçekte bir örgütün, Weber tarafından öne sürülen bütün özelliklere tamamen sahip olması oldukça güçtür (Hall, 1963). Burada ideal tip bürokrasi, araştırmacılar için bir ölçüt ya da kılavuz görevi görmektedir.

Weber'in bürokrasi kuramı, ilkelerin uygulanması, verimlilik ve amaca ulaşmayı sağladığı için işlevsel olarak nitelendirilmektedir. Ancak zaman içerisinde bürokrasi kuramının işlevsel olmayan ya da olumsuz bazı sonuçlarının da olduğu (Aydın, 2007; Hoy ve Miskel, 2010), Weber'in bu noktayı fazla önemsemediği belirtilmiştir. Nitekim bürokrasinin işgörenler ve örgüt üzerindeki etkileri konusunda araştırmacılar ve kuramcılar arasında birbirleri ile çelişen (Adler ve Borys, 1996), bürokrasi modelinin işlevsel olan ve olmayan yönlerine ilişkin iki farklı görüş bulunmaktadır. Bürokrasiyi olumsuz açıdan değerlendiren birinci görüşe göre, bürokratik modeldeki işbölümü ve uzmanlaşma, işgörenlerin uzmanlaşmasına katkı sağlamasına rağmen, monotonluğu da beraberinde getirebilir (Aydın, 2007; Hoy ve Miskel, 2010). Karar vermede ve ilişkilerde nesnellik, rasyonelliği arttırabilir. Ancak diğer taraftan duygusallıktan uzak davranılan, güvenin azaldığı monoton bir örgüt ikliminde, işgörenlerin moralleri düşebilir. Örgüt içerisindeki hiyerarşik yapı koordinasyonu attırabileceği gibi, iletişim kopukluğuna ve çarpıklığına neden olabilir. Resmi karar ve eylemlere yön veren kural ve düzenlemeler, bir taraftan süreklilik ve istikrarı sağlarken, diğer taraftan katı örgütsel kuralcılığa yol açabilir. Öyle ki bazı örgütlerde çalışanlar kurallara o kadar bağlı kalabilirler ki, amaçlara ulaşmak için bir araç olarak kullanılan kurallar amaç haline gelebilir. Benzer biçimde örgüt içerisindeki kariyer olanakları kuruma bağlılığı ve motivasyonu arttırabileceği gibi, yüksek başarı sağlayanların hızlı terfi alması işgörenler arasında memnuniyetsizliğe neden olabilir (Aydın, 2007; Hoy ve Miskel, 2010).

Kişiler arası ilişkilerin önemli rol oynadığı eğitim örgütlerinde, yapandan çok, yapılacak işi ön planda tutan ideal tip bürokrasinin uygulanması zor görülmektedir (Bursalıoğlu, 2003). Ancak, okulun da içinde bulunduğu toplumsal örgütlerin yapısı incelendiğinde, istesek de istemesek de çoğunun bürokratik özelliklere sahip oldukları görülmektedir (Buluç, 2009). Bürokrasiye ilişkin yukarıda değinilen olumlu ve olumsuz görüşleri inceleyen araştırmalardan elde edilen sonuçları ve Adler ve Borys (1996) tarafından öne sürülen kolaylaştırıcı ve engelleyici/zorlayıcı bürokrasi yaklaşımını bir arada sentezleyen Hoy ve Sweetland $(2000,2001)$, okullardaki bürokratik yapıyı farklı bir şekilde tanımlamışlardır.

Hoy ve Sweetland $(2000,2001)$ okullardaki yapıyı, bürokrasinin iki temel özelliği olan biçimlendirme ve merkezileşmeye dayandırarak incelemişlerdir. Adler ve Borys (1996) biçimlendirmeyi, bir örgütün yazılı kurallara, düzenlemelere, prosedürlere ve politikalara sahip olma düzeyi olarak tanımlamaktadır. Hoy ve Sweetland $(2000 ; 2001)$ ise; işgören davranışlarını kontrol etmeyi ve kurallara uymayanların cezalandırılmasını amaçlayan kural ve prosedürleri "engelleyici/zorlayıcı biçimlendirme", görevlerini yaparken ve karşılaştıkları sorunları çözerken işgörenlere yardımcı olmayı amaçlayan kural ve prosedürleri ise "kolaylaştırıcı biçimlendirme" olarak tanımlamışlardır. 
Adler ve Borys (1996) merkezileşmeyi, işgörenlerin karar alma sürecine katılma düzeyi olarak tanımlamaktadır. Hoy ve Sweetland (2000; 2001); işgörenlerin karşılaştıkları problemleri çözmede ve görevlerini yerine getirmede esnek, yardım edici ve işbirlikçi olan otorite yapısını "kolaylaştırıcı merkezileşme", katı, otokratik ve kontrol edici olan otorite yapısını ise "engelleyici merkezileşme" olarak ifade etmektedir.

Yukarıdaki açıklamalardan da anlaşılacağı üzere, Hoy ve Sweetland (2000; 2001) okullardaki bürokratik yapıyı açıklarken, merkezileşme ve biçimlendirmeyi düzey olarak değil, tür olarak incelemişlerdir. Örgütteki merkezileşme ve biçimlendirmenin kolaylaştırıcı ve engelleyici özellik göstermesine göre, dört farklı bürokratik okul yapısı tanımlamıştır.

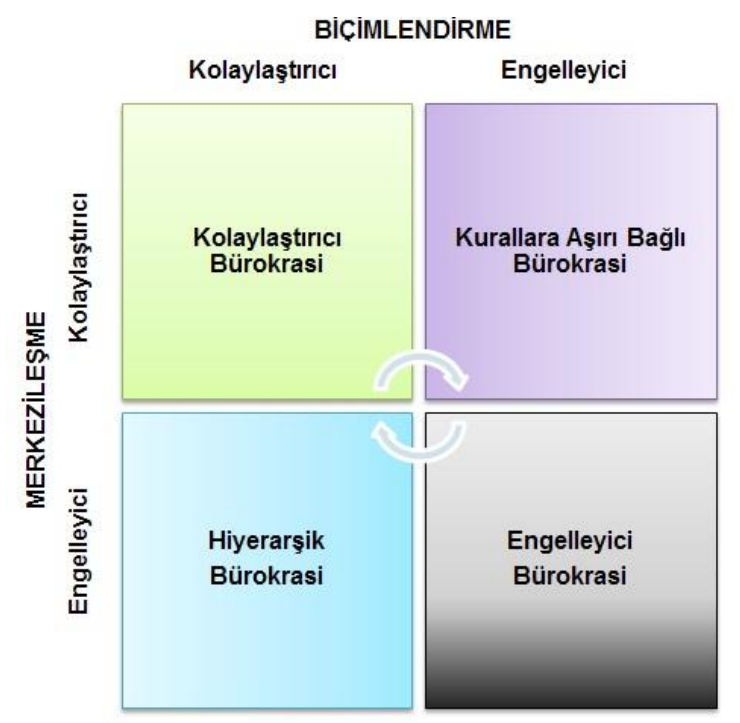

Şekil 1. Okullardaki Bürokratik Yapıya İlişkin Bir Tipoloji

Şekil 1'de gösterilen modelde, merkezileşme ve biçimlendirmenin kolaylaştırıcı özellik gösterdiği yapı "kolaylaştırıcı bürokrasi" olarak adlandırılmaktadır. Böyle bir yapıya sahip okulda, yetki yapısı engelleyici olmaktan çok yardım edici, örgüt kural ve prosedürleri ise problem yaratan ya da başarısızlıkları cezalandıran engeller olmak yerine, karşılaşılan problemlerin çözümünde yol gösteren rehberlerdir. Bu okullarda hiyerarşi ve kurallar, müdürün gücünü arttırmada araç olmak yerine, öğretmenleri destekleyen mekanizmalardır (Hoy ve Miskel, 2010). Modelde merkezileşme ve biçimlendirmenin engelleyici ya da zorlayıc özellik gösterdiği yapı ise "engelleyici bürokrasi" olarak adlandırılmaktadır. Böyle bir yapıya sahip okulda, hiyerarşi ve kurallar, kontrol ve uyumu sağlamak için kullanılır. Bu yapı, isteksiz ve sorumsuz öğretmenlerin, yöneticilerin emrettiği şekilde davranmasını sağlamak için kullanılır (Hoy ve Miskel, 2010). Bu okullardaki bürokratik yapı müdürün gücünü arttırmak için kullanılmakta, öğretmenler desteklenmekten çok engellenmektedir.

Bu açıdan bakıldığında bir okuldaki bürokratik yapının okulun işleyişini doğrudan ya da dolaylı olarak etkileyebileceği söylenebilir. Örneğin kolaylaştırıcı bir bürokratik yapı, okulda örgütsel canlılığın sağlanmasında destekleyici bir unsur olarak rol alabilir. Nitekim bürokratik yapının kolaylaştırıcı olduğu örgütlerde; problemlerin öğrenme fırsatları olarak görüldüğü, çalışanların mesleki açıdan kendilerini güçlü ve yeterli hissettikleri, yönetici ve çalışanlar arasındaki çatışmaların azaldığı, değişim ve örgüt geliştirme için işbirliği yapıldığı (Adler ve Borys, 1996; Guldan, 2004; Hoy ve Miskel, 2010; Hoy ve Sweetland; 2001; McGuigan, 2005; McGuigan ve Hoy, 2006; Tylus, 2009; Watts, 2009) belirtilmektedir. Buna karşın engelleyici bürokratik bir yapı; tipik olarak tepeden inmeci olup, tek yönlü iletişimi öngörür. Bu yapıya sahip örgütlerde yaşanan problemlerin sorun olarak görüldüğü, çalışanlar arasında 
güvensizliğin arttığı, uyumun kontrol ve ceza ile sağlandığı, yönetici ve çalışanlar arasında çatışmalar yaşandığı belirtilmektedir (Adler ve Borys, 1996; Hoy ve Miskel, 2010; Hoy ve Sweetland; 2001).

\section{Araştırmanın Amacı ve Önemi}

Bürokrasi konusuna ilişkin alanyazın incelendiğinde, bürokratik yapının etkin olarak işlediği örgütlerde; işgören performansının, motivasyonunun ve işbirliğinin arttığı (Buluç, 2009) ifade edilmektedir. Reform ve okul geliştirme çabalarının yoğun olarak yaşandığı eğitim örgütlerinde, çalışanlar arası işbirliğinin ve güvenin arttıııması açısından okulun bürokratik yapısının nasıl işlediğinin belirlenmesi oldukça önemli görülmektedir. Bu nedenle okullardaki bürokratik yapının nasıl işlediğini veya okulların bürokratiklik düzeyini belirlemek üzere pek çok araştırma yapılmaktadır. Söz konusu araştırmalarda bürokratik yapıyı ölçmek üzere birbirinden farklı pek çok ölçme aracının kullanıldığı görülmektedir. Hall (1961, Akt. Yücel, 1999) tarafından geliştirilen "Örgüt Envanteri [Organizational Inventory]", George ve Bishop (1971), Bishop ve George (1973), Murphy, Bishop ve George (1975) tarafından farklı formlar halinde geliştirilen "Yapısal Özellikler Ölçeği [Structural Properties Questionnaire], Mackay (1964) tarafından geliştirilen ve daha sonra Robinson (1966) ve Punch (1969) tarafından yeniden düzenlenen "Okul Örgüt Envanteri [School Organization Inventory], Yücel (1999) tarafından geliştirilen "Bürokratikleşme Anketi", Öztürk (2001) tarafından geliştirilen "Okulların Bürokratik Özellikleri Ölçeği”, Demir (2005) tarafından geliştirilen "Kara Harp Okulunun Bürokratik Yapısı ve İşleyişi Ölçeği", Ermeç (2007) tarafından geliştirilen "ilköğretim Okulları Bürokratikleşme Düzeyi Ölçeği", Hoy ve Sweetland (2001) tarafından geliştirilen ve Buluç (2009) tarafından Türkçe'ye uyarlanan Okul Yapısının Etkililiği Ölçeği” bunlardan bazılarıdır. Ölçtüğü özellikler, boyutları, madde sayısı ve cevaplama süresi gibi ölçütler açısından incelendiğinde; ulusal (Buluç, 2009; Erdoğan, 2012; Önal, 2012) ve uluslararası alan yazında öğretmenlerin okullardaki bürokratik yapıya ilişkin algılarını belirlemek üzere Okul Yapısının Etkililiği Ölçeği'nin yaygın olarak kullanıldığı söylenebilir. Okul Yapısının Etkililiği Ölçeği Türkçeye ve Türk kültürüne Buluç (2009) tarafından uyarlanmıştır. Ancak Buluç (2009) çalışmasında uyarlaması yapılan ölçme aracının geçerliğini belirlemek üzere sadece açımlayııı faktör analizi yöntemini kullanmıştır. Bu araştırma ile Buluç(2009) tarafından uyarlanan ölçme aracı aynen kullanıımış, ancak elde edilen veriler üzerinden ölçeğin psikometrik özelliklerinin yeniden incelenmesi, açımlayıcı faktör analizinin yanı sıra doğrulayıcı faktör analizinin de yapılması amaçlanmıştır. Böylelikle, öğretmenlerin okullarındaki bürokratik yapıya ilişkin algılarını ölçmeyi amaçlayan ölçeğin, geçerlik ve güvenirliğine ilişkin yeni kanıtlar elde edilecektir.

\section{Yöntem}

\section{Çalışma Grubu}

Araştırmanın katılımcıları, 2009-2010 eğitim-öğretim yılında, Malatya ili merkez ilçe belediye sınırları içerisinde yer alan 75 farklı ilköğretim okulunda görev yapan toplam 1018 öğretmenden oluşmaktadır. Araştırmaya katılan öğretmenlerin demografik özellikleri incelendiğinde, 471'inin (\%46.3) kadın, 547'sinin (\%53.7) erkek olduğu, 926'sının (\%90.4) devlet okullarında, 98'inin (\%9.6) ise özel okullarda görev yaptığı belirlenmiştir. Araştırmaya katılan öğretmenlerin kıdem ortalaması ise 15.7 yıl olarak hesaplanmıştır.

\section{Veri Toplama Aracı}

Araştırmada kapsamında, öğretmenlerin görev yaptıkları okullardaki örgüt yapısının bürokratiklik düzeyine ilişkin algılarını belirlemek üzere, orijinali Hoy ve Sweetland (2000) tarafından geliştirilen ve Türkçeye uyarlaması, geçerlik ve güvenirlik çalışmaları Buluç (2009) tarafından yapılan, "Okul Yapısının Etkililiği [Enabling School Structure]" ölçeğinin faktör yapısı incelenmiştir. Ölçeğin orijinal formu "Hiçbir Zaman" ile "Her Zaman" arasında beşli olarak derecelendirilen, okuldaki bürokratik yapının öğretmenlerin işlerini yaparken kolaylaştırıcı mı, engelleyici mi olduğunu belirlemeyi amaçlayan on iki maddeden oluşmaktadır. Buluç (2009) tarafından yapılan uyarlama çalışması sonucunda ölçeğin, Hoy ve 
Sweetland (2000) tarafından geliştirilen orijinal formda olduğu gibi, tek boyut ve on iki maddeden oluşan bir faktör yapısına sahip olduğu belirlenmiştir. Tek boyutlu ölçeğin açıkladığı kümülatif varyans oranı "\% 43.26", Cronbach Alpha güvenirlik katsayısı ise “.88" olarak hesaplanmıştır (Buluç, 2009).

\section{Verilerin Analizi}

Ölçme aracı geliştirme ya da uyarlama sürecinde ölçekten elde edilen puanların geçerliliğine dair en önemli özelliklerden biri yapı geçerliliğidir. Yapı geçerliliği gözlenebilen değişkenler aracılığıyla gözlenemeyen değişkenlere ilişkin yapılan çıkarımların geçerliliğini test eder (Çokluk, Şekercioğlu ve Büyüköztürk, 2010). Sosyal bilimlerde geliştirilen ölçeklerin yapı geçerliliğinin test edilmesinde sıklıkla faktör analizi tekniğine başvurulmaktadır (Büyüköztürk, 2010). Faktör analizinde kullanılan iki temel yöntem açımlayıcı ve doğrulayıcı faktör analizidir. Açımlayııı faktör analizinde araştırmacı araştırmasının henüz ilk safhalarında aralarında ilişki olan değişkenleri bir araya toplayarak eldeki veri setini tanımlamaya ya da özetlemeye çalışır (Pallant, 2011; Tabachnick ve Fidell, 2007). Doğrulayıcı faktör analizinde ise değişkenler arasındaki ilişkiden hareketle oluşturulan yapıya ilişkin hipotezin ya da teorinin karmaşık ve üst düzey analizlerle sınanması amaçlanır (Büyüköztürk, 2010; Tabachnick ve Fidell, 2007). $\mathrm{Bu}$ araştırmada Okul yapısının Etkililiği Ölçeğinin yapı geçerliğini belirlemek üzere öncelikli olarak açımlayıcı faktör analizi (AFA), daha sonra ise doğrulayıcı faktör analizi (DFA) yapılmıştır. Güvenirlik çalışmaları kapsamında ise, madde-toplam korelasyon katsayıları, Cronbach Alpha iç tutarlılık katsayıları hesaplanmıştır.

\section{Bulgular}

Bu bölümde, ölçeğin geçerlik ve güvenirlik çalışmaları kapsamında yapılan analizlere yer verilmiştir.

\section{Açımlayıcı Faktör Analizi Sonuçları}

Bu araştırmada, Buluç (2009) tarafından uyarlanan ölçeğin faktör yapısını incelemek üzere 1018 öğretmenden elde edilen veriler üzerinden AFA yapılmıştır. Faktör analizi yapılmadan önce, verilerin faktör analizine uygunluğu Kaiser-Meyer-Olkin (KMO) katsayısı ve Bartlett küresellik testi ile test edilmiştir. Elde edilen değerler, verilerin faktör analizi için uygun olduğunu göstermiştir (KMO $=.873$, Bartlett Test of Sphericity $=3836.437, p=.000$ ). Bu aşamadan sonra ölçeğin yapı geçerliliğini belirleyebilmek için elde edilen veriler üzerinden temel bileşenler analizi yöntemine göre AFA yapılmıştır (Büyüköztürk, 2010; Pallant, 2011). Faktör analizi sonucunda elde edilen bulgular aşağıdaki tabloda verilmiştir.

Tablodaki bulgular incelendiğinde, engelleyici bürokrasi boyutunda yer alan maddelerin faktör yüklerinin ".557" ile ".832" arasında, açıkladıkları ortak varyans oranlarının ".324" ile ".694" arasında, madde-toplam korelasyon katsayılarının ise ".436" ile ".704" arasında değiştiği görülmektedir. Kolaylaştırıcı bürokrasi boyutunda yer alan maddelerin ise faktör yüklerinin ".485" ile ".785" arasında, açıkladıkları ortak varyans oranlarının ".340" ile ".608" arasında, madde-toplam korelasyon katsayılarının ise ".332" ile ".615" arasında değiştiği görülmektedir. Faktör analizi sonucunda elde edilen iki faktörlü ölçek, toplam varyansın \% 50.751'ini açıklamaktadır. Kline (1994) toplam varyansı açıklama düzeyinin \%30'ın üzerinde olmasını, yapı geçerliği için önemli göstergelerden biri kabul etmektedir. Yapılan analizler sonucunda ölçeğin Cronbach Alpha iç tutarlılık katsayıları birinci boyut için ".806", ikinci boyut için ise ".774" olarak hesaplanmıştır.

Bu araştırmada yapılan AFA sonucunda, Hoy ve Sweetland (2000) ve Buluç (2009) tarafından yapılan çalışmaların aksine, ölçekte yer alan maddelerin iki faktörde yüksek yük değerlerine sahip oldukları belirlenmiştir. Bu nedenle ölçeğin faktör yapısına ilişkin bu farkıılığın kuramsal olarak nasıl yorumlanması gerektiği konusunda, ölçeğin orijinal formunu geliştiren araştırmacılardan biri ile (Wayne K. Hoy) ile email yoluyla iletişime geçilmiş, bu araştırmadan elde edilen iki faktörlü yapıyı değerlendirmesi istenmiştir. Söz konusu araştırmacı, ölçek maddelerini oluştururken aslında kendilerinin de iki faktörlü 
bir yapı (engelleyici bürokrasi ve kolaylaştırıcı bürokrasi) düşündüklerini, dolayısıyla bu araştırmada elde edilen iki faktörlü yapının beklentilere uygun bir sonuç olduğunu ifade etmiştir. Bu aşamadan sonra elde edilen iki faktörlü yapı için model-veri uyumunu değerlendirmek amacıyla DFA yapılmıştır.

Tablo 1

Kolaylaştırıcı Okul Yapısı Ölçeğine ilişskin Faktör Analizi Sonuçları (n=1018).

\begin{tabular}{|c|c|c|c|c|}
\hline \multirow{2}{*}{ Madde } & \multicolumn{2}{|c|}{ Faktör Yükleri } & \multirow{2}{*}{$\begin{array}{c}\text { Faktör } \\
\text { Ortak } \\
\text { Varyansı } \\
\end{array}$} & \multirow{2}{*}{$\begin{array}{c}\text { Düzeltilmiş Madde- } \\
\text { Toplam } \\
\text { Korelasyonları }\end{array}$} \\
\hline & Faktör 1 & Faktör 2 & & \\
\hline 7.Yönetsel kurallar öğretmenleri cezalandırmak için kullanılır. & .799 & & .642 & .645 \\
\hline 9.Bu okulda yönetsel kurallar mesleki kararların yerine geçer. & .703 & & .511 & .522 \\
\hline 5.Yönetsel kurallar engelleyici değil yardım edicidir. & & .785 & .608 & .615 \\
\hline $\begin{array}{l}\text { 10.Bu okuldaki yönetsel kurallar katı ve engelleyici değil çözüm } \\
\text { üretmeye rehberlik edicidir. }\end{array}$ & & .759 & .579 & .606 \\
\hline $\begin{array}{l}\text { 1.Bu okuldaki yönetsel kurallar öğretmenler ve yöneticiler } \\
\text { arasında güvenilir bir iletişim kurulmasını sağlar. }\end{array}$ & & .714 & .498 & .551 \\
\hline $\begin{array}{l}\text { 3.Bu okulun yönetsel hiyerarşisi öğretmenlerin işlerini yapmasına } \\
\text { imkan verir. }\end{array}$ & & .705 & .512 & .561 \\
\hline Açıklanan Kümülatif Varyans & 26.025 & 24.726 & $\% 50.751$ & \\
\hline Cronbach Alpha & .806 & .774 & & \\
\hline
\end{tabular}

Faktör 1:Engelleyici Bürokrasi, Faktör 2: Kolaylaştırıcı Bürokrasi

\section{Doğrulayıcı Faktör Analizi Sonuçları}

DFA analizleri Lisrel 8.71 (Jöreskog ve Sörbom, 2004) kullanılarak yapılmış, analizlerde en çok olabilirlik yöntemi kullanılmıştır. Doğrulayıc faktör analizi sonundan elde edilen uyum iyiliği değerlerinin yorumlanmasında alanyazında genel kabul gören bazı ölçütler bulunmaktadır. DFA çalışmalarında; " $\mathrm{X}^{2} / \mathrm{sd}$ " oranının 2 ya da daha az olması, GFI, AGFI, NNFI ve CFI değerlerinin ".95" ya da üzerinde olması, RMSEA, RMR ve SRMR değerlerinin ise ".05" ve altında olması model-veri uyumunun mükemmel olduğunun göstergesi olarak kabul edilmektedir. Buna karşın; " $\chi^{2} / s d$ " oranının 2 ile 5 arasında olması, $\mathrm{GFI}, \mathrm{AGFI}$, NNFI ve CFI değerlerinin ".90" ya da üzerinde olması, RMSEA, RMR ve SRMR göstergelerinde ise ".08" den küçük olması model-veri uyumunun kabul edilebilir düzeyde olduğunun göstergesi olarak kabul edilmektedir (Brown, 2006, Çokluk, Şekercioğlu ve Büyüköztürk, 2010; Sümer, 2000; Şimşek, 2007; 
Tabachnick ve Fidell, 2007). Yapılan ilk DFA sonucunda, AFA analizi sonucunda elde edilen iki faktörlü yapıya ilişkin uyum iyiliği değerlerinin, alan yazında kabul edilebilir ve mükemmel olarak nitelendirilen değerler arasında olduğu görülmüştür. DFA sonucunda uyum indeksleri $\chi^{2}=215.48, s d=51, \chi^{2} / s d=4.22$, RMSEA=0.056, RMR=0.036, SRMR=0.040, GFI=0.97, $\mathrm{AGFI}=0.95, \mathrm{NFI}=0.94, \mathrm{CFI}=0.96, \mathrm{IFI}=0.96$ olarak bulunmuştur. Ölçek maddeleri ile faktörler arasındaki ilişkiye ilişkin değerler incelendiğinde maddelerin ilişkili oldukları örtük değişkenle olan ilişki katsayılarının 0.44 ile 0.82 arasında değiştiği (Bkz. Şekil 2) belirlenmiştir. Model - veri uyumuna ilişkin yukarıda belirtilen değerlerin tamamı dikkate alındığında, iki faktörlü modelin veriyle mükemmele yakın uyum verdiği, bu nedenle ölçeğin yapısal geçerliğe sahip olduğu söylenebilir.

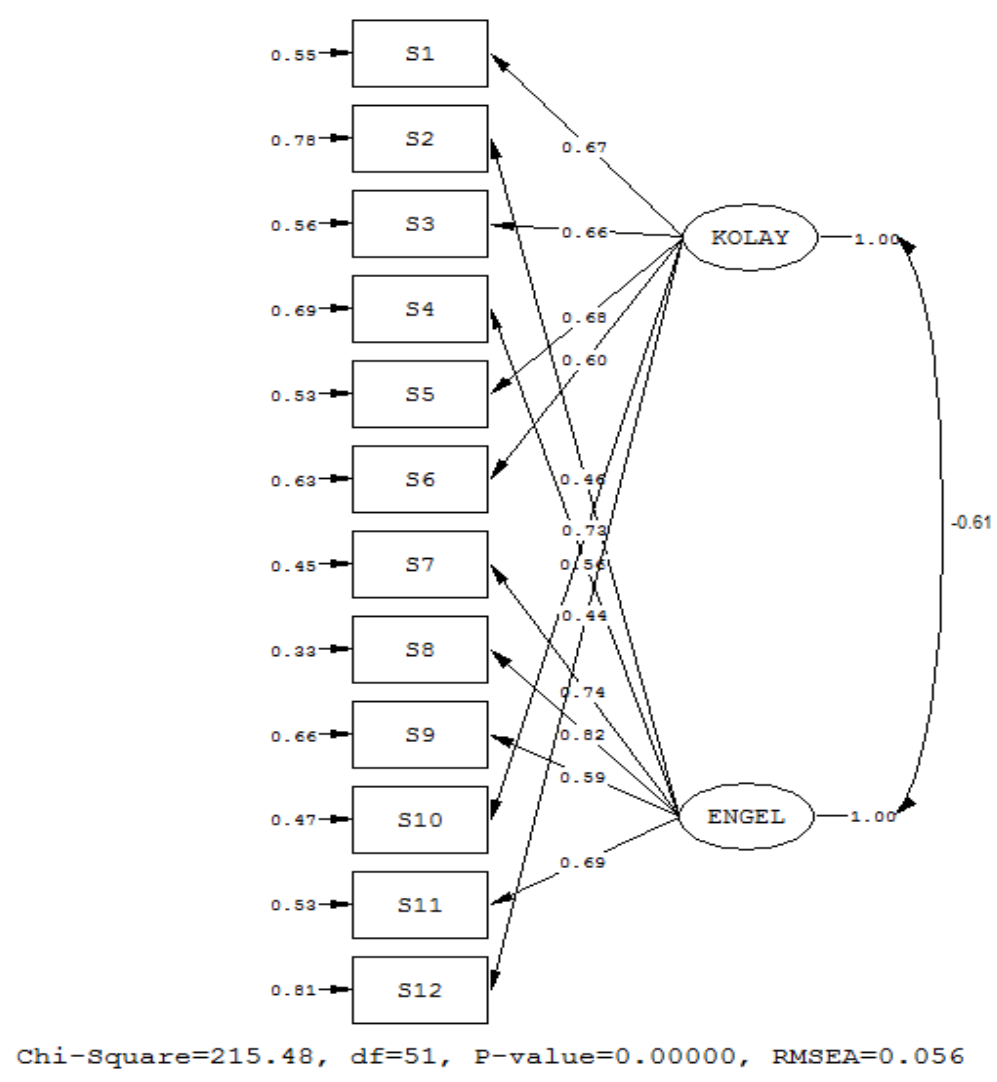

Şekil 2. Doğrulayıcı Faktör Analizi Sonuçlarına İlişkin Path Diyagramı

\section{Sonuç, Tartışma ve Yorum}

Bu araştırma ile okullardaki bürokratik yapının kolaylaştırıcı mı engelleyici mi olduğunu belirlemek üzere geliştirilen "Okul Yapısının Etkililiği” ölçeğinin faktör yapısının ve psikometrik özelliklerinin yeniden incelenmesi amaçlanmıştı. Malatya ilinde görev yapan 1018 öğretmenden toplanan veriler üzerinden yapılan açımlayıcı faktör analizi sonucunda; ölçekte yer alan maddelerin, Hoy ve Sweetland (2000) ve Buluç (2009) tarafından yapılan çalışmaların aksine, iki önemli faktör altında yüksek yük değerlerine sahip olduğu belirlenmiştir. İki faktörlü yapıda birinci faktörde yer alan maddelerin faktör yüklerinin “.557” ile ".832" arasında, açıkladıkları ortak varyans oranlarının “.324” ile “.694" arasında, maddetoplam korelasyon katsayılarının ise ".436" ile ".704" arasında değiştiği belirlenmiştir. İkinci faktörde yer alan maddelerin ise faktör yüklerinin ".485" ile ".785" arasında, açıkladıkları ortak varyans oranlarının “.340” ile “.608” arasında, madde-toplam korelasyon katsayılarının “.332" ile “.615” arasında değiştiği belirlenmiştir. İki faktörlü ölçekte yer alan 12 madde toplam varyansın yaklaşık olarak \% 51'ini 
açıklamaktadır. Ölçeğin Cronbach Alpha iç tutarlılık katsayıları birinci faktör için ".806", ikinci faktör için ise ".774" olarak hesaplanmıştır. Bu aşamadan sonra, iki faktörlü yapıya ilişkin model-veri uyumunu değerlendirmek amacıyla ayrıca DFA yapılmıştır. Yapılan DFA sonucunda uyum indeksleri $\chi^{2}=215.48$, $\mathrm{sd}=51, \chi^{2} / \mathrm{sd}=4.22, \mathrm{RMSEA}=0.056, \mathrm{RMR}=0.036, \mathrm{SRMR}=0.040, \mathrm{GFI}=0.97, \mathrm{AGFI}=0.95, \mathrm{NFI}=0.94, \mathrm{CFI}=0.96$, $|F|=0.96$ olarak bulunmuştur. DFA analizlerinden elde edilen bu bulgular ölçeğin yapı geçerliğini sağladığını göstermektedir. Araştırmada yapılan AFA ve DFA sonucunda elde edilen bulgular ışığında, “Okul Yapısının Etkililiği Ölçeği”nin Türkçe formunun, iki faktörlü olarak kullanılmasının daha uygun olduğu söylenebilir. Ölçekte yer alan maddelerden altısı okuldaki kolaylaştııııı bürokratik yapıyı ölçmeye dönük ifadelerden oluşmakta iken, diğer altısı okuldaki engelleyici ya da zorlayıcı bürokratik yapıyı ölçmeye dönük ifadelerden oluşmaktadır. Engelleyici bürokrasi boyutunda yer alan maddeler, okuldaki bürokratik yapının öğretmenlerin işlerini yapmalarını ne düzeyde engellediğini ölçen altı maddeden oluşmaktadır. Kolaylaştıııı bürokrasi boyutunda yer alan altı madde ise, okuldaki bürokratik yapının öğretmenlerin işlerini yapmalarını ne düzeyde kolaylaştırdığını ölçmektedir. Birinci boyuttan alınan puanların yükselmesi, okuldaki bürokratik yapının engelleyici olduğunu, ikinci boyuttan alınan puanların yükselmesi ise okuldaki bürokratik yapının kolaylaştıııı olduğunu göstermektedir.

\section{Kaynakça}

Adler, P. ve Borys, B. (1996). Two types of bureaucracy: Enabling and coercive. Administrative Science Quarterly, 41, 61-89.

Aydın, M. (2007). Eğitim yönetimi (7. Baskı). Ankara: Hatiboğlu Basım ve Yayım San. Tic. Ltd. Şti.

Balcı, A. (1991). Eğitim yönetiminde kuram ve araştırma. Ankara Üniversitesi Eğitim Bilimleri Fakültesi Dergisi, 24(2), 735- 746.

Bishop, L. K. ve George, J. R.(1973). Organizational structure: A factor analysis of structure characteristics of public elementary and secondary school. Educational Administration Quarterly, 9(3), 66-80.

Brown, T.A. (2006). Confirmatory factor analysis for applied research. New York: Guilford Press.

Buluç, B. (2009). İlköğretim okullarında bürokratik okul yapısı ile okul müdürlerinin liderlik stilleri arasındaki ilişki. Eğitim ve Bilim, 34(152), 71-86.

Bursalığlu, Z. (2003). Eğitim yönetiminde teori ve uygulama (7. Baskı). Ankara: Pegem A Yayıncılık.

Büyüköztürk, Ş. (2010). Sosyal bilimler için veri analizi el kitabı (11.Baskı). Ankara: Pegem Akademi.

Çokluk, Ö., Şekercioğlu, G, ve Büyüköztürk, ş. (2010). Sosyal bilimler için çok değişkenli istatistik. Ankara: Pegem A Yayıncilık.

Demir, S. (2005). Öğretim üyelerinin kara harp okulunun bürokratik özellikleri ve işleyişine ilişkin görüşleri. Yayımlanmamış yüksek lisans tezi, Ankara Üniversitesi, Eğitim Bilimleri Enstitüsü-Ankara.

Erdoğan, U. (2012). Illköğretim okullarının bürokratik yapıları ile öğretmenlerin örgütsel sosyalleşme düzeyleri arasındaki ilişki (Malatya İli Örneği). Yayımlanmamış yüksek lisans tezi, İnönü Üniversitesi, Eğitim Bilimleri Enstitüsü-Malatya.

Ermeç, E. G. (2007). Illköğretim okullarının bürokratikleşme düzeyi ile öğretmen morali arasındaki ilişkiler. Yayımlanmamış yüksek lisans tezi, Pamukkale Üniversitesi, Sosyal Bilimler Enstitüsü-Denizli.

Etzioni, A. (1964). Modern organizations. Englewood Cliffs, New Jersey: Prentice-Hall, Inc.

George, J. R. ve Bishop, L. K. (1971). Relationship of organizational structure and teacher personality characteristics to organizational climate. Administrative Science Quarterly, 16(4), 467-475.

Guldan, E. A. (2004). Enabling bureaucracy, faculty trust, and collective efficacy in selected catholic elementary schools. Unpublished doctoral dissertation, St. John's University- Queens, New York. 
Niyazi ÖZER ve Burhanettin DÖNMEZ - Pegem Eğitim ve Öğretim Dergisi, 3(4) 2013, 57-68

Hall, R. H. (1963). The concept of bureaucracy: An empirical assessment. American Journal of Sociology; 69(1), 32-40.

Hoy, W. ve Sweetland, S. (2000). School bureaucracies that work: Enabling, not coercive. Journal of School Leadership, 10(6), 525-541.

Hoy, W. K., ve Sweetland, S. R. (2001). Designing better schools: The meaning and nature of enabling school structure. Educational Administration Quarterly, 37, 296-321.

Hoy, W. K. ve Miskel, C. G. (2010). Eğitim yönetimi: Teori, araştırma ve uygulama (7. Baskıdan Çeviri). S. Turan (Çev. Ed.), Ankara: Nobel Yayın Dağıtım.

Hoy, W. K. ve Sweetland, S. (2001). Designing better schools: The meaning and measure of enabling school structures. Educational Administration Quarterly, 37(3), 296-321.

Kline, P. (1994). An easy guide to factor analysis. London: Routledge.

MacKay, D. A. (1964). An empirical study of bureaucratic dimensions and their relationship to other characteristics of school organizations. Unpublished doctoral dissertation, University of Alberta-Edmonton, Alberta.

McGuigan, L. (2005). The role of enabling bureaucracy and academic optimism in academic achievement growth. Unpublished doctoral dissertation, The Ohio State University- Columbus, $\mathrm{OH}$. [UMI Number: 3179683].

McGuigan, L. ve Hoy, W. K. (2006). Principal leadership: Creating a culture of academic optimism to improve achievement for all students. Leadership and Policy in Schools, 5(3), 203-229.

Murphy, M.J., Bishop, L.K., ve Goerge, J. R. (1975). Defining organizational properties of schools: A focus on structure. Paper presented at the Annual Meeting, AERA, Washington, D.C.

Önal, H. (2012). İlköğretim kurumlarında örgüt kültürü ile bürokrasi arasındaki ilişki. Yayımlanmamış yüksek lisans tezi, Gazi Üniversitesi, Eğitim Bilimleri Enstitüsü-Ankara.

Öztürk, N. (2001). Liselerde bürokratikleşme ve öğretmenlerin stres düzeyleri. Yayımlanmamış doktora tezi, Dokuz Eylül Üniversitesi Eğitim Bilimleri Enstitüsü-İzmir.

Pallant, J. (2011). SPSS survival manual: A step by step guide to data analysis using SPSS for Windows (4. Baskı). Berkshire: Open University Press.

Punch, K. F. (1969) Bureaucratic structure in schools: Towards redefinition and measurement. Education Administration Quarterly. 5(2), 43-57.

Robinson, N. (1966). A study of the professional role: Orientation of teachers and principals and their relationship to bureaucratic characteristics of school organizations. Unpublished doctoral dissertation: University of Alberta-Edmonton, Alberta.

Sümer, N. (2000). Yapısal eşitlik modelleri: Temel kavramlar ve örnek uygulama. Türk Psikoloji Yazıları, $3(6), 49-73$.

Şimşek, Ö. F. (2007). Yapısal eşitlik modellemesine giriş: Temel ilkeler ve LISREL uygulamaları. Ankara: Ekinoks Yayıncılık.

Tabachnick, B. G. ve Fidell, L. S. (2007). Using multivariate statistics (5th ed.). Boston: Allyn and Bacon.

Tortop, N., İşbir, E. ve Aykaç, E. (1993). Yönetim bilimi. Ankara: Yargı Yayınları.

Tylus, J. D. (2009). The impact of enabling school structures on the degree of internal school change as measured by the implementation of pprofessional learning communities. Unpublished doctoral dissertation, Virginia Commonwealth University-Richmond, Virginia. [UMI Number: 3388625]. 
Udy, S. Jr. (1958). "Bureaucratic" elements in organizations: Some research findings. American Sociological Review, 23(4), 415-418.

Udy, S. Jr. (1959). Bureaucracy and rationality in Weber's organizational theory: An emprical study. Administrative Science Quarterly, 24(6), 791-795.

Watts, D. M. (2009). Enabling school structure, mindfulness, and teacher empowerment: Test of a theory. Unpublished doctoral dissertation, The University of Alabama-Tuscaloosa, Alabama. [UMI Number: 3390602].

Weber, M. (1996). Sosyoloji yazıları. (Çev. T. Parla). İstanbul: İletişim Yayınları.

Yayla, Y. (2001). Kanuni Sultan Süleyman devri Osmanlı Devleti'nde bürokratik yapı (1520-1566). Yayımlanmamış yüksek lisans tezi, Süleyman Demirel Üniversitesi, Sosyal Bilimler Enstitüsü-Isparta.

Yücel, C. (1999). Bureaucracy and teachers' sense of power. Unpublished doctoral dissertation, Virginia Polytechnic Institute and State University- Virginia. [UMI Number: 3147768].

Zeytin, N. (2009). Illköğretim okullarında bürokratikleşme ve okul kültürü. Yayımlanmamış yüksek lisans tezi, Dokuz Eylül Üniversitesi, Eğitim Bilimleri Enstitüsü-İzmir. 
Niyazi ÖZER ve Burhanettin DÖNMEZ - Pegem Eğitim ve Öğretim Dergisi, 3(4) 2013, 57-68 